\title{
EFFECT OF THE GSTM1 GENOTYPE ON THE BIOMARKERS OF EXPOSURE TO POLYCYCLIC AROMATIC HYDROCARBONS: META-ANALYSIS
}

\author{
DANDAN LI ${ }^{1}$, BINGLING WANG ${ }^{1}$, GUOCHANG FENG ${ }^{1}$, MENG XIE ${ }^{2}$, LIJUAN WANG ${ }^{1}$, and RUQIN GAO ${ }^{1}$ \\ ${ }^{1}$ Qingdao Centers for Disease Control and Prevention, Qingdao, China \\ ${ }^{2}$ Qingdao University, Qingdao, China \\ School of Public Health, Department of Epidemiology and Health Statistics
}

\begin{abstract}
The role of glutathione S-transferase Mu 1 (GSTM1) in the biomonitoring of polycyclic aromatic hydrocarbons (PAHs) is not clear. Our purpose has been to evaluate the influence of GSTM1 genotypes on 1-hydroxypyrene (1-OHP), deoxyribonucleic acid (DNA) adducts, and micronucleus frequency in both occupational and non-occupational populations of null and active GSTM1 carriers. We conducted a meta-analysis on 25 articles that met our strict inclusion criteria (11 studies on 1-OHP, 9 on DNA adducts, and 5 on the micronucleus frequency). In the case of occupationally exposed workers, micronucleus frequency was only significantly higher in the null GSTM1 carriers than in the active GSTM1 carriers. In the non-occupationally exposed general population, 1-OHP and micronucleus frequency were significantly higher in the null GSTM1 carriers. The results of Egger's test and funnel plot analysis indicated no significant publication bias. In conclusion, GSTM1 genotypes may affect the urinary 1-OHP in the non-occupationally exposed general population, and micronucleus frequency in both occupational workers and non-occupational population. Int J Occup Med Environ Health 2017;30(2):177-201
\end{abstract}

\section{Key words:}

Polymorphism, Micronuclei, Meta-analysis, 1-Hydroxypyrene, DNA adducts, GSTM1

\section{INTRODUCTION}

There is much evidence showing that exposure to polycyclic aromatic hydrocarbons (PAHs) is associated with an increase in the incidence of respiratory and cardiovascular diseases and lung cancer in populations from occupational [1,2] as well as non-occupational environments [3-6]. Polycyclic aromatic hydrocarbons are formed during incomplete combustion processes and are released into ambient air due to industrial emissions, vehicle exhaust, domestic heating and cigarette smoking which emit a wide variety of genotoxic agents [7-9]. Occupationally exposed populations, such as coke oven workers, chimney sweeps, traffic police, professional drivers, street vendors and ecological operators, have more opportunities for exposure to PAHs. As a family of semi-volatile organic compounds, PAHs concurrently have both aerosol particulate

Funding: this study was partly supported by grants from the National Natural Science Foundation of China ("Effects of postnatal exposure to polycyclic aromatic compounds in settled house dust on the neurodevelopment of urban toddlers" No. 81372955). Project manager: Bingling Wang, Ph.D.

Received: June 25, 2016. Accepted: September 23, 2016.

Dandan Li, Bingling Wang, and Guochang Feng contributed equally to this work and should be all considered as 1st authors.

Corresponding author: R. Gao, Qingdao Centers for Disease Control and Prevention, 175 Shandong Road, Qingdao 266033, China (e-mail: gaoruqin@yeah.net). 
and gas phases and may be cumulated in the house dust. Therefore, PAH exposure is very common for the general population, especially for young children [10].

Biomarkers of internal exposure to PAHs include urinary 1-hydroxypyrene (1-OHP) [11,12], and PAH-DNA (deoxyribonucleic acid) and PAH-protein adducts, and in effect biomarkers include DNA damage, chromosomal aberrations, sister chromatid exchanges and micronuclei. 1-Hydroxypyrene, a metabolite of the PAH pyrene [13], is considered the main biomarker currently available for measuring exposure to PAHs. This is because pyrene is present in high amounts in all mixtures of PAHs, and the correlation between external pyrene exposure and internal 1-OHP levels has been shown [14].

After metabolic activation catalyzed by a series of enzymes, some PAHs bind covalently to DNA to form the damaging DNA-PAH adducts [15]. Deoxyribonucleic acid adduct is considered to be a biomarker of carcinogen exposure, and to some extent, reflects individual susceptibility [16-18]. The measurement of bulky DNA adducts in white blood cells have been shown in human to correlate with the level of PAHs in lung tissue [19,20].

Activated PAHs in the human body are detoxified by phase II enzymes such as glutathione S-transferase M1 (GSTM1), which makes PAH metabolites, such as 1-OHP, more water soluble and suitable for excretion [21]. Glutathione S-transferase M1 has well-defined null and active genotypes, and it has been reported that the null GSTM1 genotype causes a homozygous deletion that could result in functional loss of this enzyme [22]. Hence, the ability of null GSTM1 carriers to eliminate PAH metabolites is reduced; therefore, for individuals with this genotype, the PAH biomarker levels are generally higher [23].

Liu et al. [24] were the first to conduct a meta-analysis to investigate the influence of the GSTM1 genotype on the formation of DNA adducts. Their results showed that the DNA adduct levels in null GSTM1 carriers were significantly higher than those in active GSTM1 carriers among workers who were occupationally exposed to PAHs. However, in this meta-analysis, 2 important occupational field studies $[25,26]$ that met the inclusion criteria were not included. Moreover, one of the studies included did not investigate the bulky adduct but the benzo[a]pyrene diol epoxide adduct. The detection methods for these 2 kinds of adducts are completely different, and it has concurrently been shown that the bulky adduct is a better biomarker when both environmental exposure and exposure as a result of lifestyle habits, such as smoking, are considered [27]. Polycyclic aromatic hydrocarbons exposure causes DNA adduct formation and DNA oxidation, which eventually leads to DNA damage [28] and may result in chromosome loss or chromosome breakage, and genetic instability, and might eventually trigger cancer. Micronucleus frequency in peripheral blood lymphocytes has been used as a sensitive biomarker of chromosomal damage, genetic instability and even cancer risk $[29,30]$. Therefore, the micronucleus frequency in peripheral blood lymphocytes is a potential effect biomarker of PAH exposure.

Given that there clearly is the need for better measures of exposure in both occupational workers and non-occupationally exposed general population for improving the quantitative risk assessment of PAHs, in this study we have performed a meta-analysis on the level of bulky adducts present in white blood cells as a biomarker of PAHs. As stated before, the previous meta-analysis by Liu et al. [24] did not include 2 important occupational field studies. Moreover, as reports on the influence of the GSTM1 status on the 1-OHP level and micronucleus frequency have been inconsistent, our other aim has been to determine the robustness of 1-OHP and micronucleus frequency as biomarkers in active GSTM1 as well as null carriers.

\section{METHODS}

Because of the heterogeneity of the included studies, both the Meta-analysis Of Observational Studies in Epidemiology (MOOSE) and Preferred Reporting Items for Sys- 
tematic review and Meta-Analysis Protocols (PRISMA-P) were used [31,32].

\section{Search strategy and data collection}

Relevant publications were searched for in 2 frequently-used on-line databases - PubMed and Web of Science - from January 1994 to March 2015. The literature search was conducted in April 2015 and the search terms used were "1-OHP" (or "1-hydroxypyrene"), "DNA adducts" (or "aromatic DNA adducts"), "micronucleus frequency", "GSTM1 polymorphism" (or "glutathione Stransferase M1"), and "PAH" (or "polycyclic aromatic hydrocarbons"). Only papers published in English were collected. All the literature was reviewed by 2 independent reviewers. Then, articles that met the following specific inclusion and exclusion criteria were included in the meta-analysis.

\section{Inclusion and exclusion criteria}

Inclusion criteria:

- the study must compare the 1-OHP in urine, DNA adduct levels and micronucleus frequency in peripheral blood lymphocytes of subjects with active GSTM1 and null GSTM1 carriers between occupationally exposed workers and the non-occupationally exposed population;

- the study must clearly describe the GSTM1 genotyping method and equipment and the method and equipment for the measurement of 1-OHP, DNA adduct, and micronucleus frequency.

Exclusion criteria:

- family-based studies, reviews, abstracts, comments, editorials and letters were excluded;

- studies with incomplete or overlapping data were excluded;

- finally, studies that did not use high-pressure liquid chromatograph (HPLC), ${ }^{32} \mathrm{P}-$ post-labeling assay, and cytokinesis-block micronucleus (CBMN) assay for the detection of 1-OHP, DNA adduct and micronuclei frequency, respectively, were also excluded.

\section{Statistical analysis}

The meta-analysis was performed using the RevMan software (version 5.3, Cochrane Community, London, UK) and STATA software (version 11.0, STATA Corp., College Station, USA). The 1-OHP and DNA adduct levels and micronuclei frequency were used in the analysis only in the mean and standard deviation form. For articles that provided the median and range values, the mean and standard deviation were calculated using the formula provided by Hozo et al. [33]. The transferring method provided by Higgins et al. [34] for the geometric mean or related parameters was applied.

The random-effects model and fixed-effects model were used for combining the results of the meta-analysis. The standardized mean difference (SMD) in the groups of each study and the overall SMD were calculated. The corresponding 95\% confidence intervals (CIs) were also computed. Heterogeneity and variance among studies were evaluated using the $\mathrm{Chi}^{2}$ test (with a significance level set at $\mathrm{p}<0.10)$, and the inconsistency index $\left(\mathrm{I}^{2}\right)$ was also calculated $\left(\mathrm{I}^{2}>50 \%\right.$ suggesting substantial heterogeneity). Then, the appropriate effect model was chosen according to the results of the heterogeneity test, and the publication bias was determined using Egger's test and the funnel plot analysis.

\section{RESULTS}

\section{Study selection}

We obtained 78 studies that met the study criteria of 1-OHP. An additional article was found by a hand search. After reviewing the full texts, we only included articles that used HPLC for detecting 1-OHP. Eleven studies were finally included in the meta-analysis [35-45]. Table 1 lists these studies and their main features.

We found 155 articles on the DNA adduct levels, GSTM1 polymorphisms and PAH exposure, includ- 


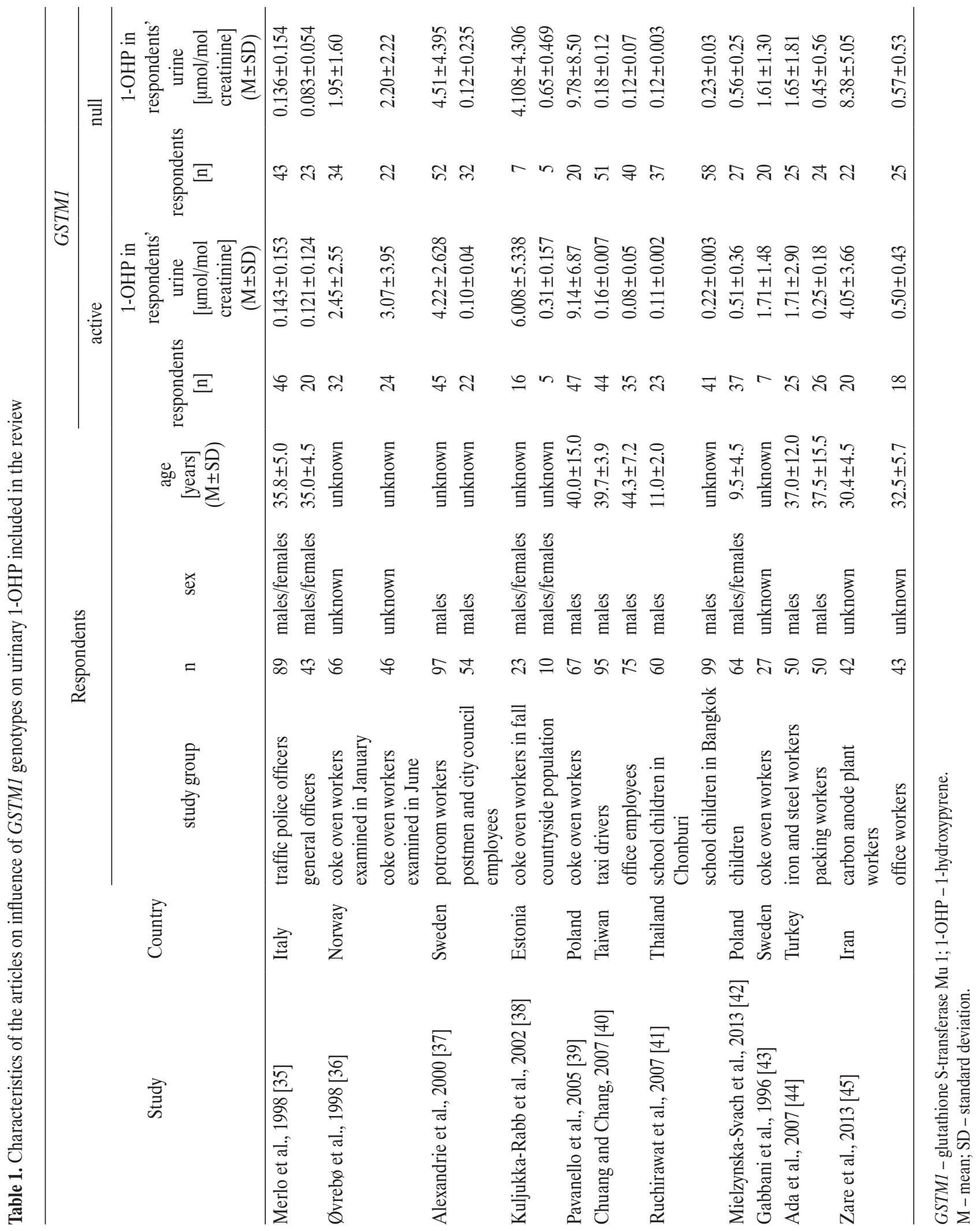


ing 2 papers that were found after a hand search. After all the articles were reviewed, the measurement of bulky PAH-DNA adduct levels in white blood cells using the ${ }^{32}$ P-Postlabeling assay was additionally included as an inclusion criterion. Finally, 9 eligible studies were included in this meta-analysis (Table 2) [25,26,38,46-51]. In total, 56 papers that investigated the micronucleus frequency, GSTM1 polymorphisms and exposure to PAHs were found. The CBMN assay measures all cells including necrotic and apoptotic cells as well as the number of nuclei per cell to provide a measure of cytotoxicity and mitotic activity. The CBMN assay has in fact evolved into a "cytome" method for comprehensive measurement of chromosomal instability and altered cellular viability caused by genetic defects or exogenous genotoxins [52]. The use of the CBMN assay and binucleated cells for determining the micronucleus frequency [53] were also considered as inclusion criteria. Finally, 5 papers were selected after the screening (Table 3) [42,54-57].

\section{Effect of the GSTM1 genotype on urinary 1-OHP}

Twenty study groups were extracted. Subjects with the active GSTM1 genotype had significantly lower 1-OHP levels than those with the null GSTM1 genotype. The heterogeneity was so high that random-effect model was used $\left(\mathrm{Chi}^{2}\right.$ coefficient $=90.27, \mathrm{p}<0.001$, $\left.\mathrm{I}^{2}=79 \%\right)$. After 1 subgroup was removed, the effect of the GSTM1 was remained, and the fixed-effects model was used according to the heterogeneity $\left(\mathrm{Chi}^{2}\right.$ coefficient $\left.=26.44, \mathrm{p}>0.05, \mathrm{I}^{2}=32 \%\right)$. The overall SMD between the subjects with active GSTM1 and null GSTM1 carriers was -0.16 (95\% CI: $-0.28-(-0.04)$, $\mathrm{Z}=2.53, \mathrm{p}=0.01$ ) (Table 4$)$. No significant publication bias was found by Egger's test ( $p=0.132$ ) or the funnel plot analysis (Figure 1a.1).

The 19 study groups comprised 11 occupational and 8 nonoccupational groups that were separated for the further meta-analysis (Tables 5 and 6). A remarkably significant difference was found in the 1-OHP levels between subjects with the active GSTM1 genotype and those with the null GSTM1 genotype only in the non-occupational populations with a SMD $=-0.29$ (95\% CI: $-0.48-(-0.1)$ ). The heterogeneity test indicated a low level of inconsistency in both groups, with a $\mathrm{p}$ value of $0.23\left(\mathrm{I}^{2}=27 \%\right)$ and $0.13\left(\mathrm{I}^{2}=29 \%\right)$, respectively. The funnel plots also showed only a small publication bias (Figure 1a.2 and 1a.3).

\section{Effect of the GSTM1 genotype \\ on the DNA adduct levels}

Combining the results of the 9 selected studies showed that there was no significant difference in the adduct levels between the subjects with the active GSTM1 genotype and those with the null GSTM1 genotype, even after the study groups were divided into the occupational workers and non-occupational groups (Tables 7-9). The heterogeneity test showed low level of inconsistency in all groups, with $\mathrm{p}$ values all $>0.3$ and $\mathrm{I}^{2}<15 \%$. No significant publication bias was found according to the result of Egger's test ( $p>0.05)$, or from the funnel plot (Figure 1b.1-3).

\section{Effect of the GSTM1 genotype}

\section{on the micronucleus frequency}

In the articles in which the micronucleus frequency was considered, the subjects who had an active GSTM1 genotype seemed to have a remarkably lower micronucleus frequency than the null GSTM1 carriers, with an $\mathrm{I}^{2}$ value of $93 \%$. Because of the high heterogeneity, 3 articles [58-60] were excluded from the analysis, after which the heterogeneity decreased significantly to $41 \%(\mathrm{p}=0.1)$ for the remaining studies. However, the effect of the GSTM1 genotype on the micronucleus frequency was still evident, with a SMD $=-0.33$ (95\% CI: $-0.5-(-0.17), \mathrm{p}<0.0001)$ (Table 10). Moreover, there was no remarkable evidence of a publication bias according to the funnel plot (Figure 1c.1). In the 4 occupational groups, a significant difference was found in the micronucleus frequency between the workers 


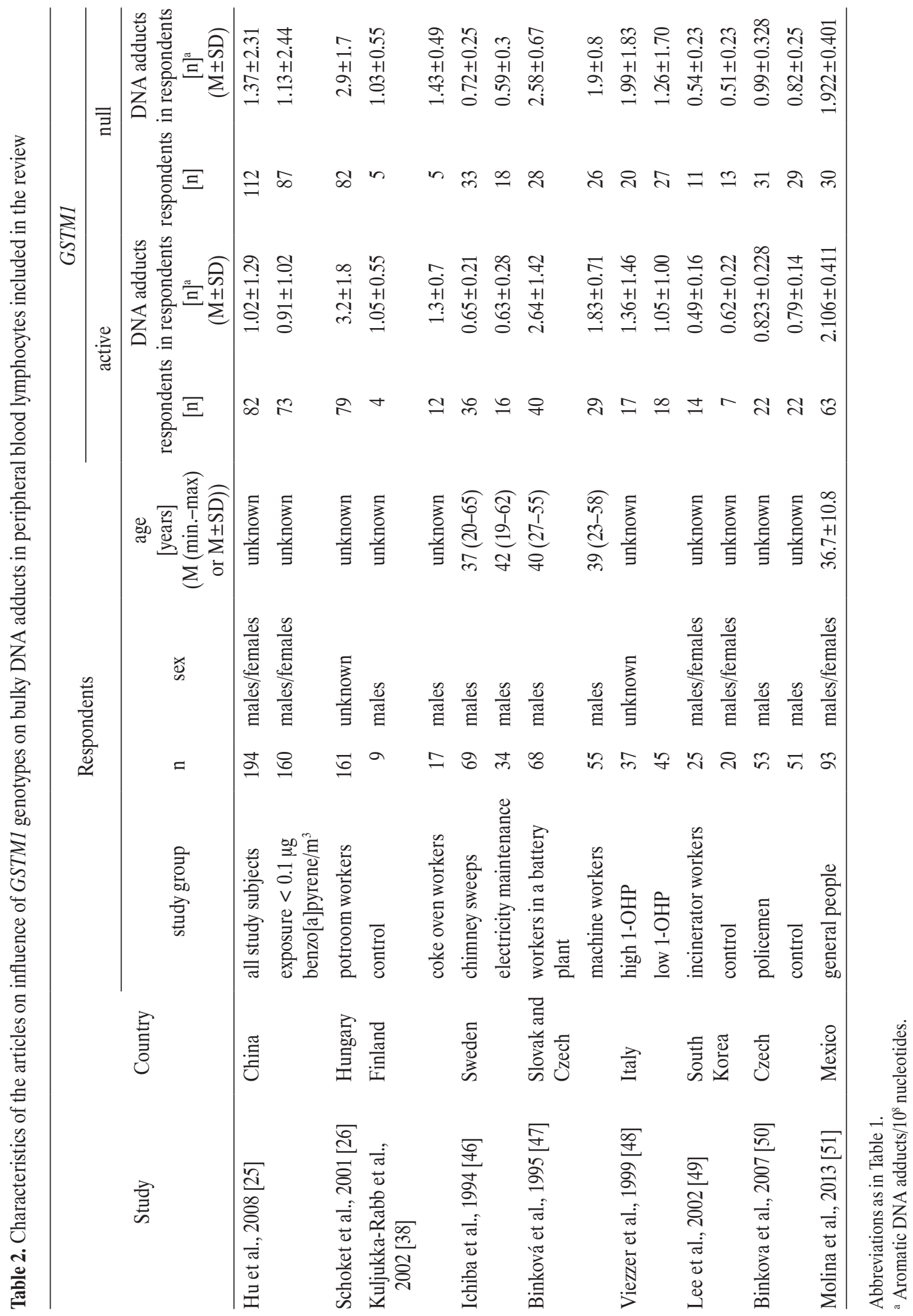




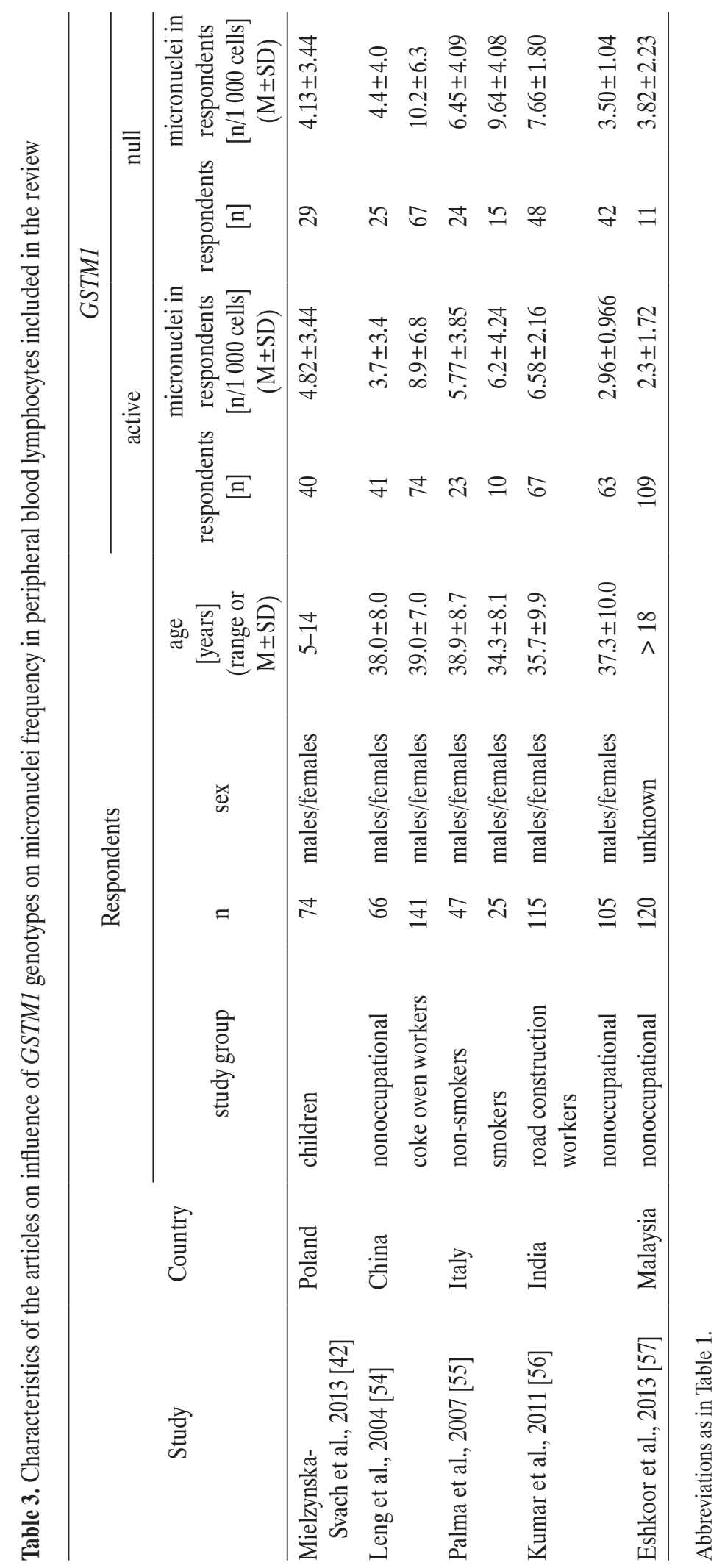




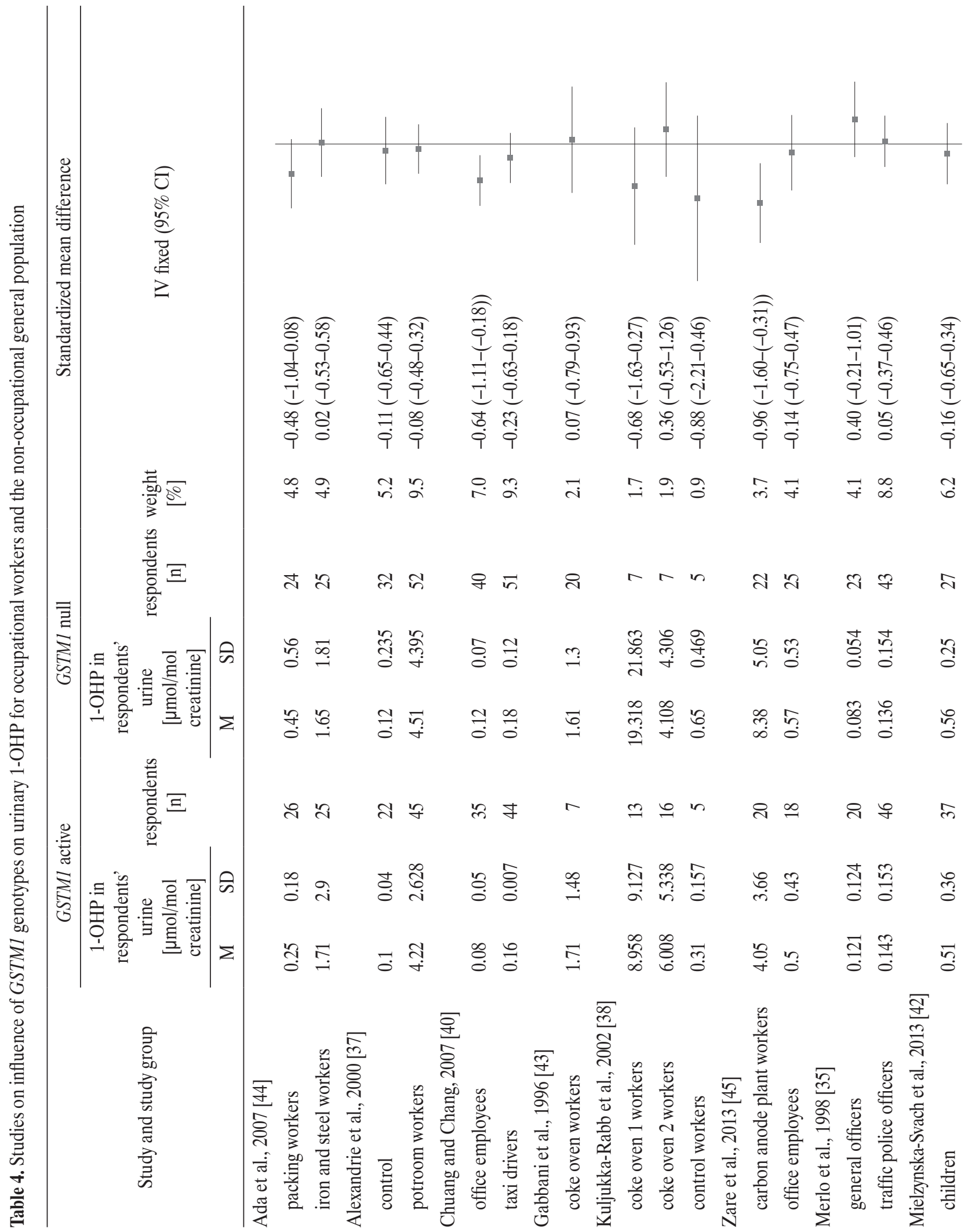




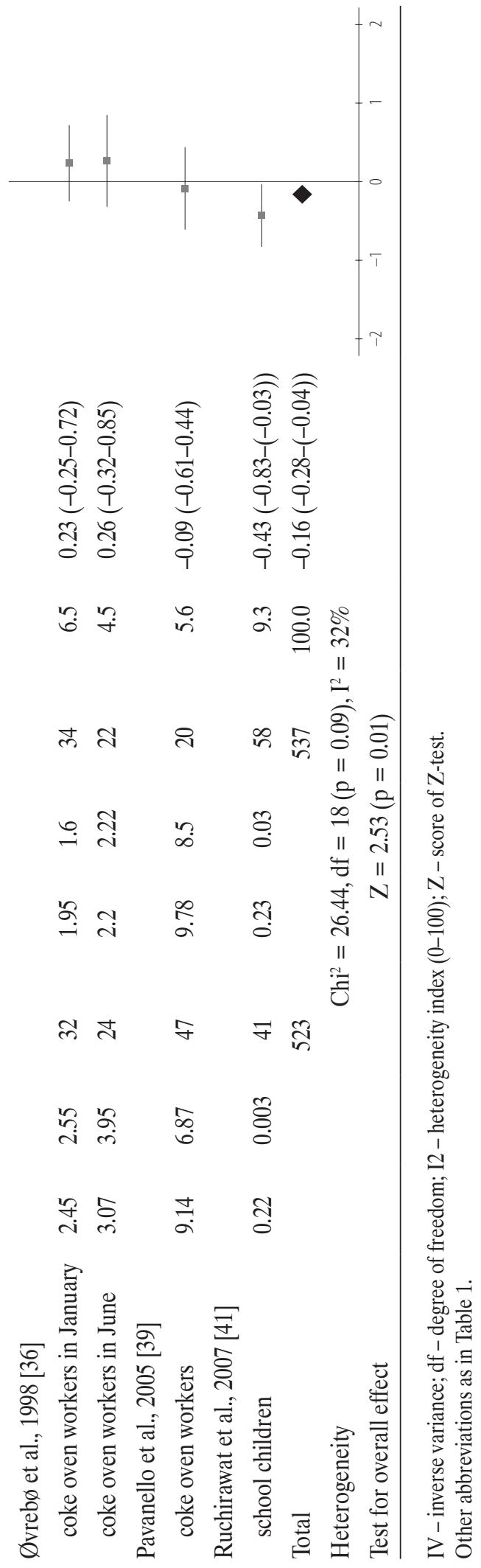



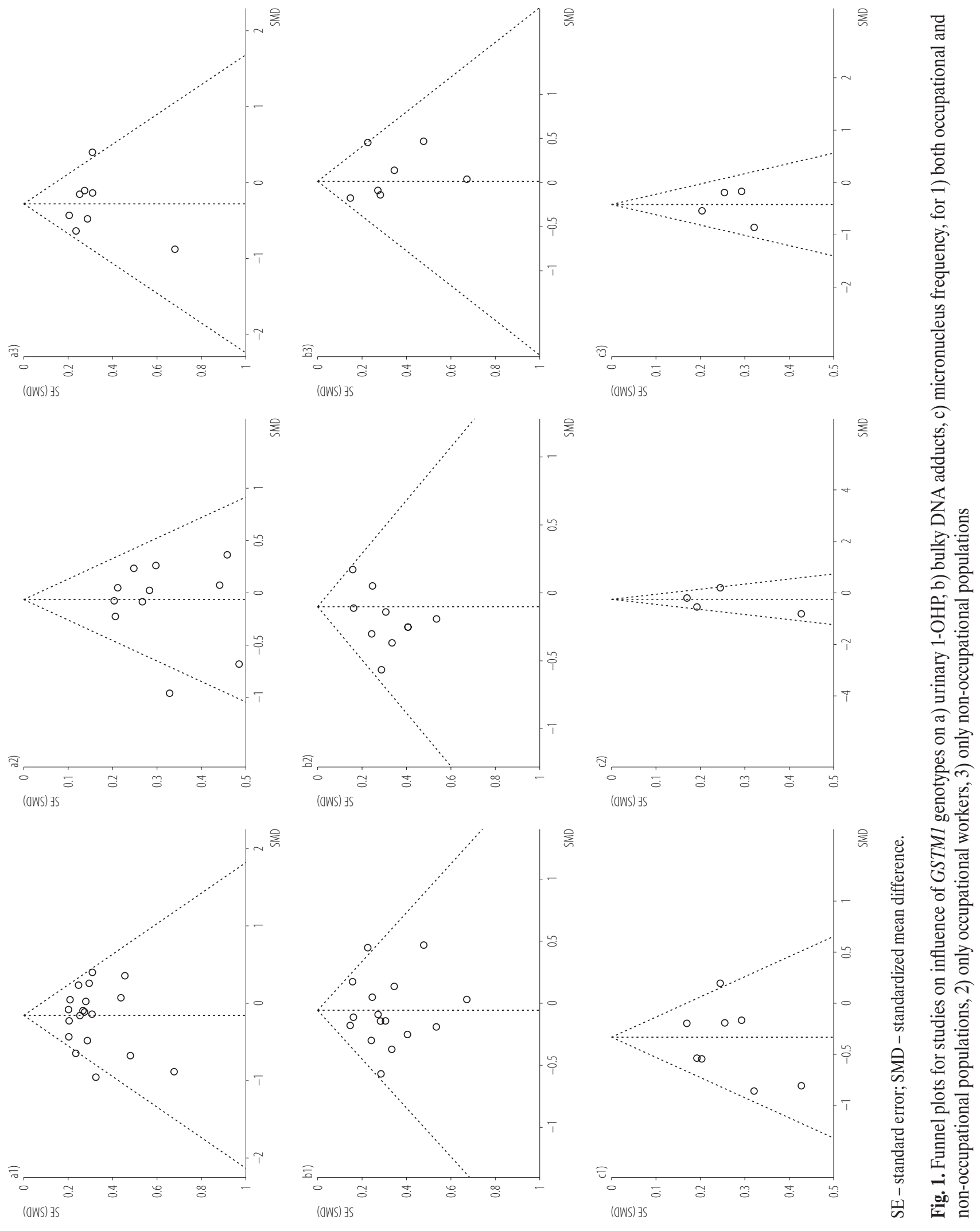

186 IJOMEH 2017;30(2) 


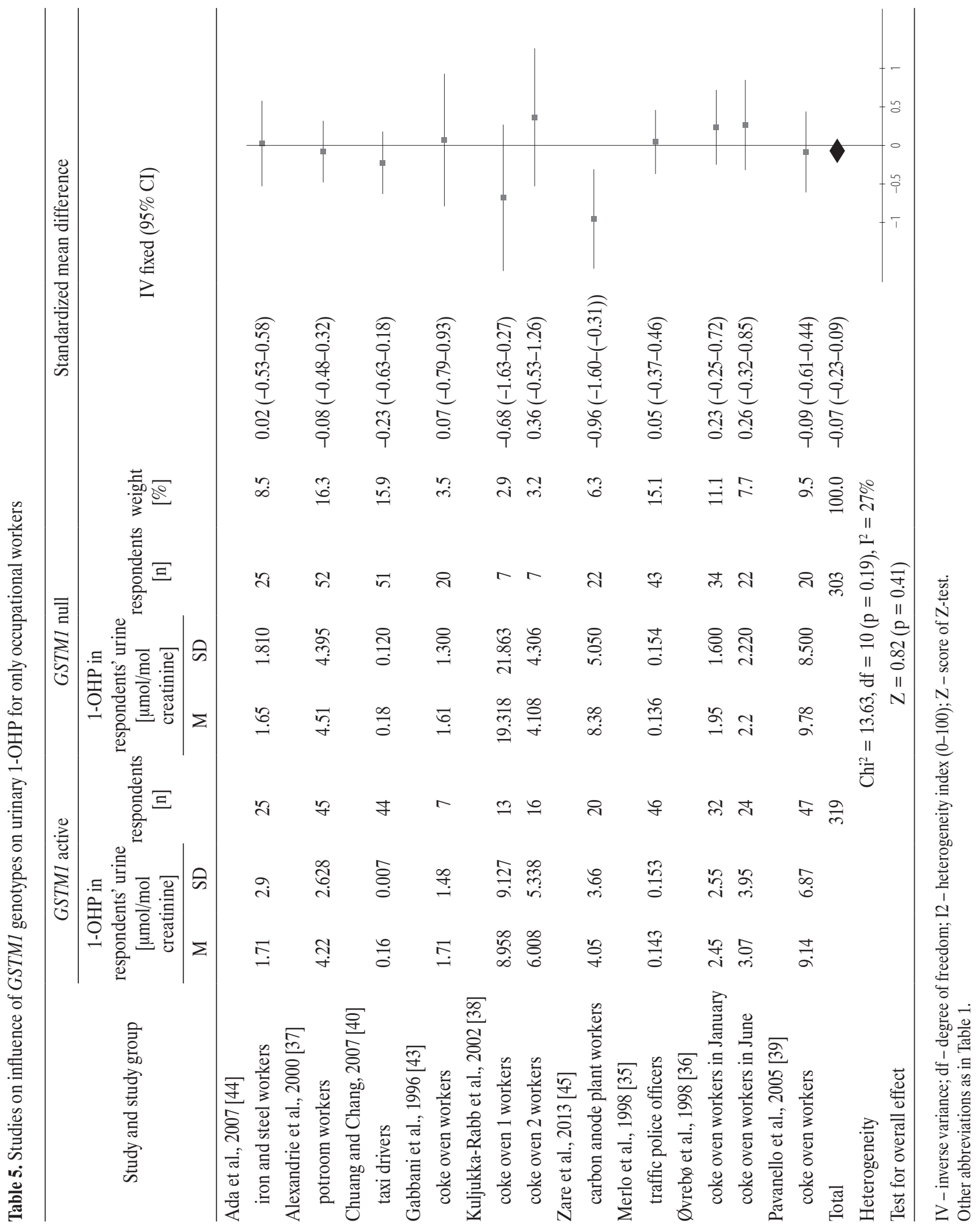




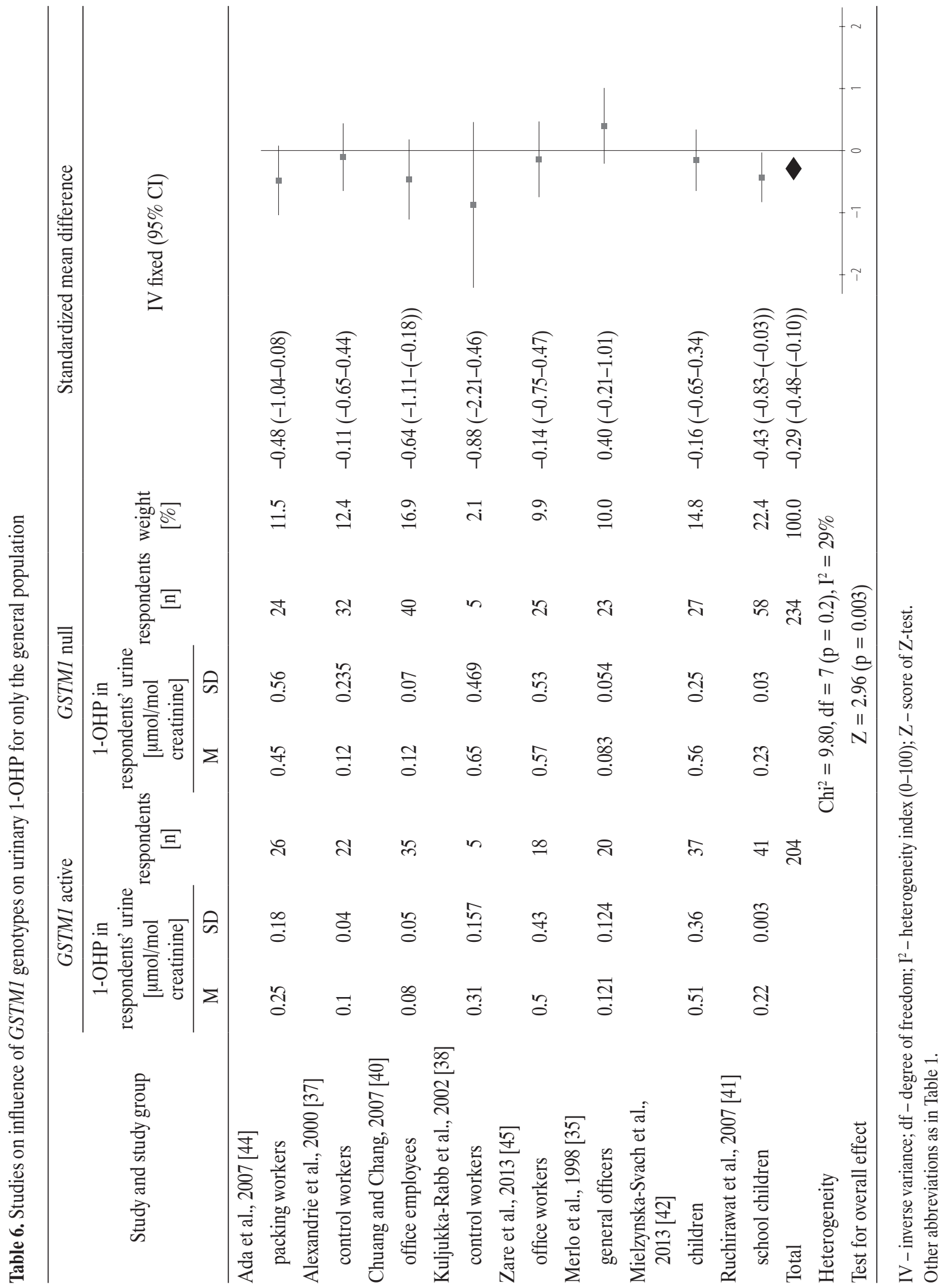




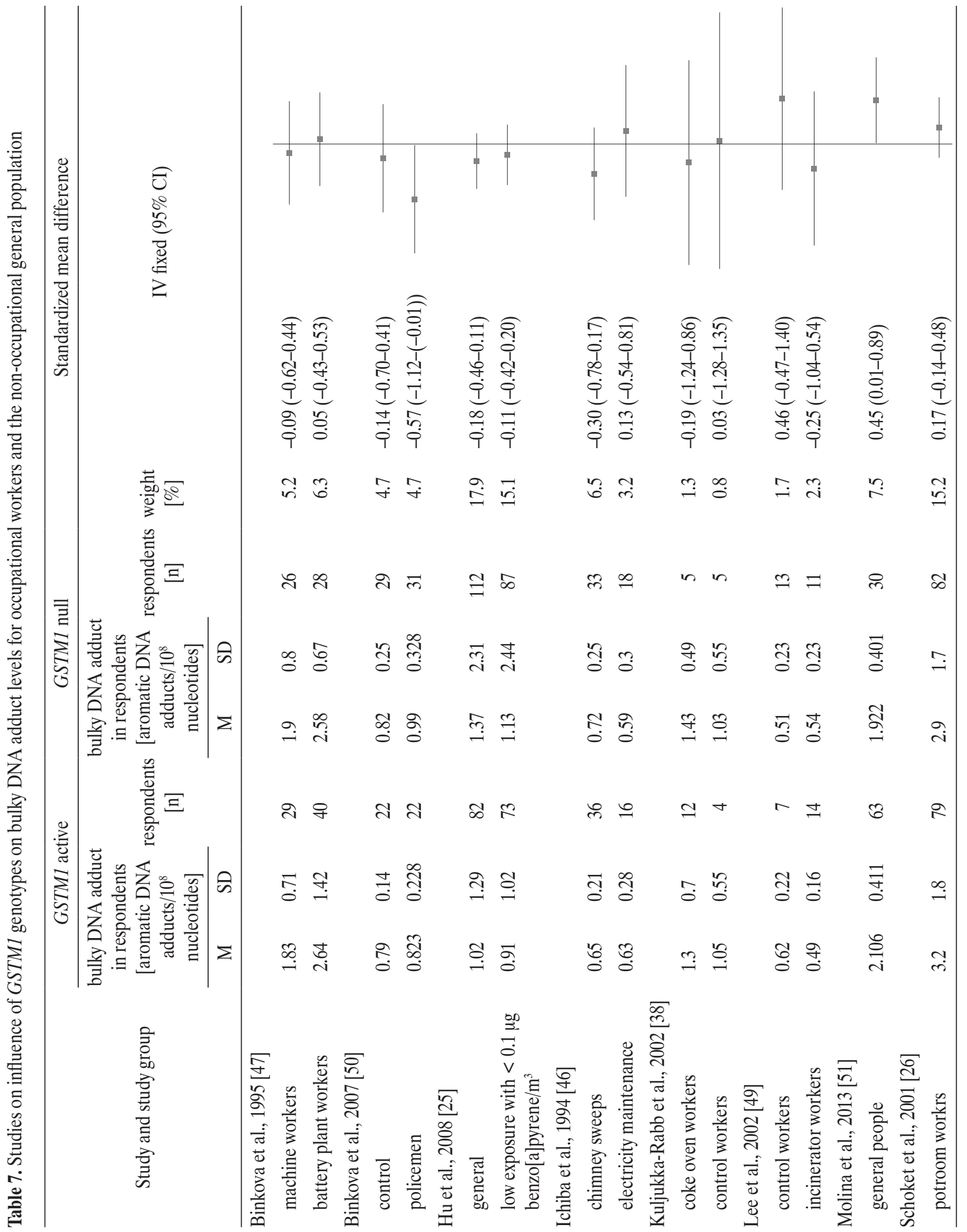




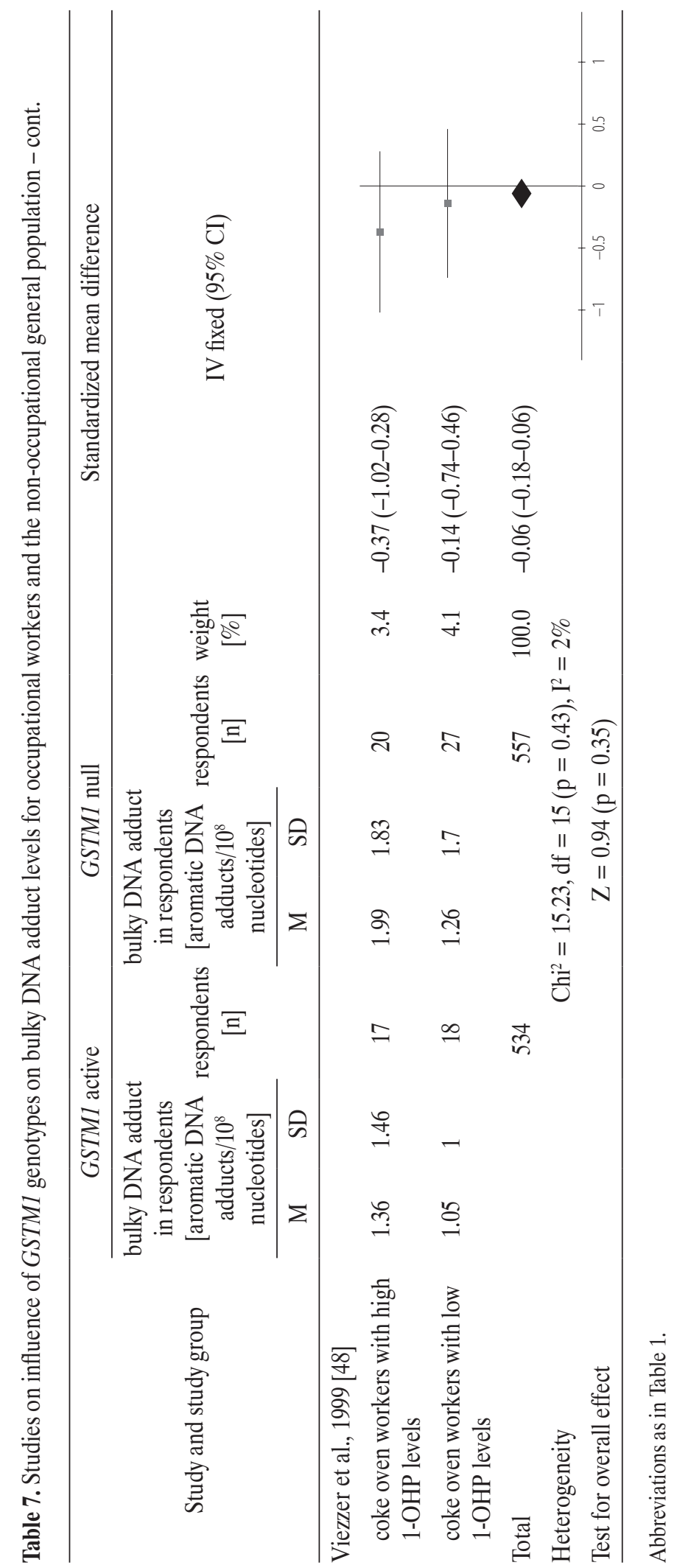




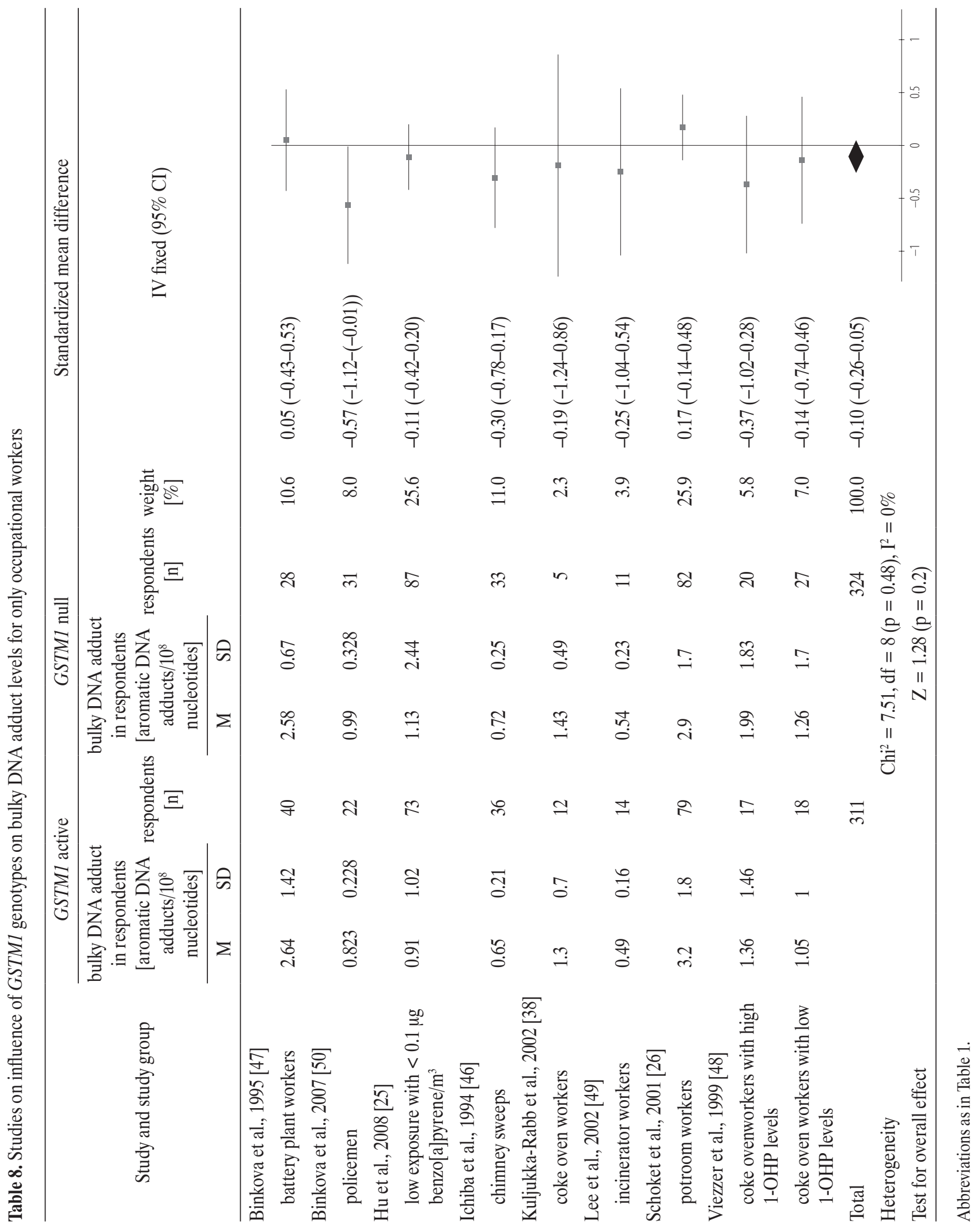




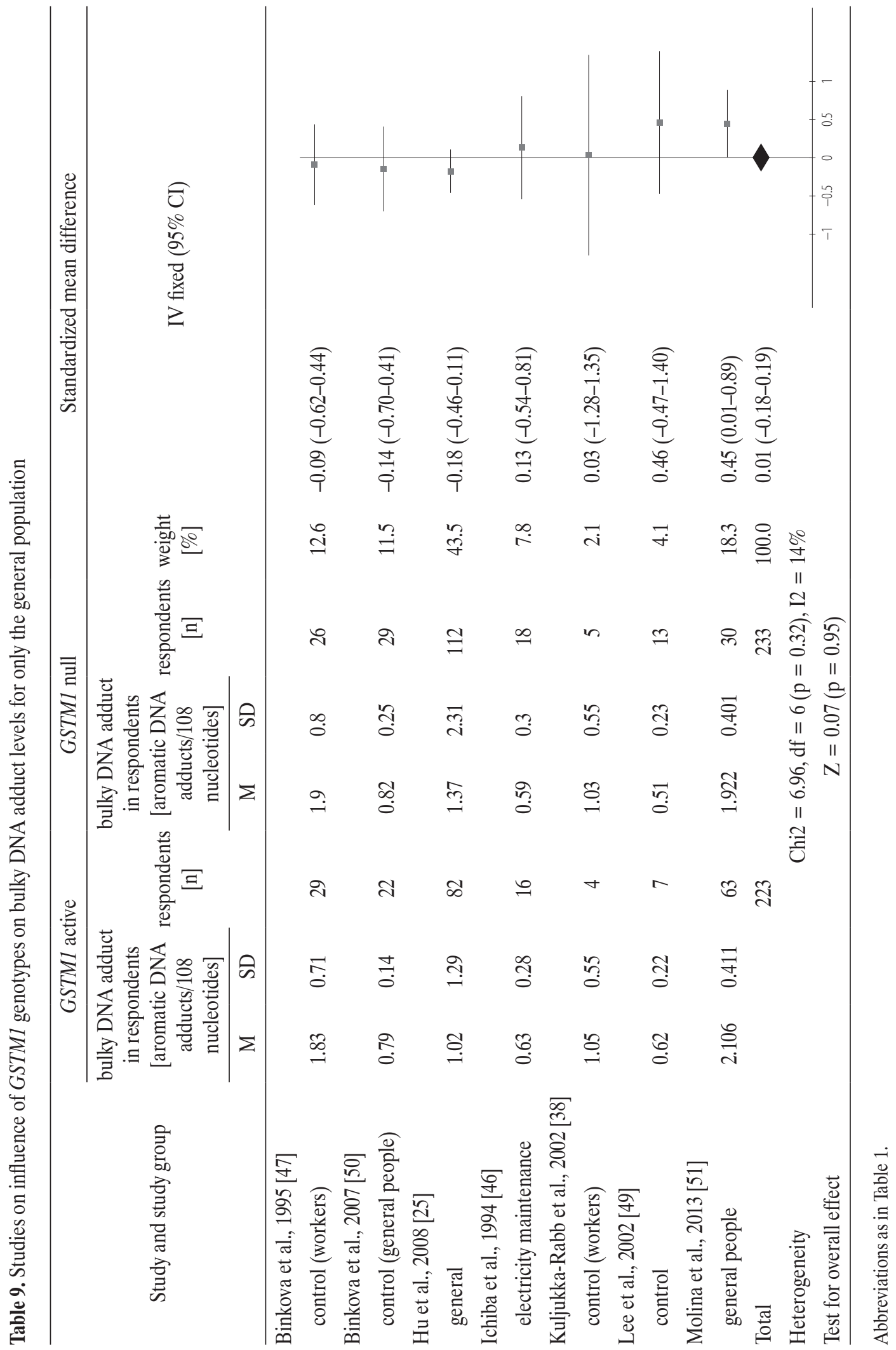




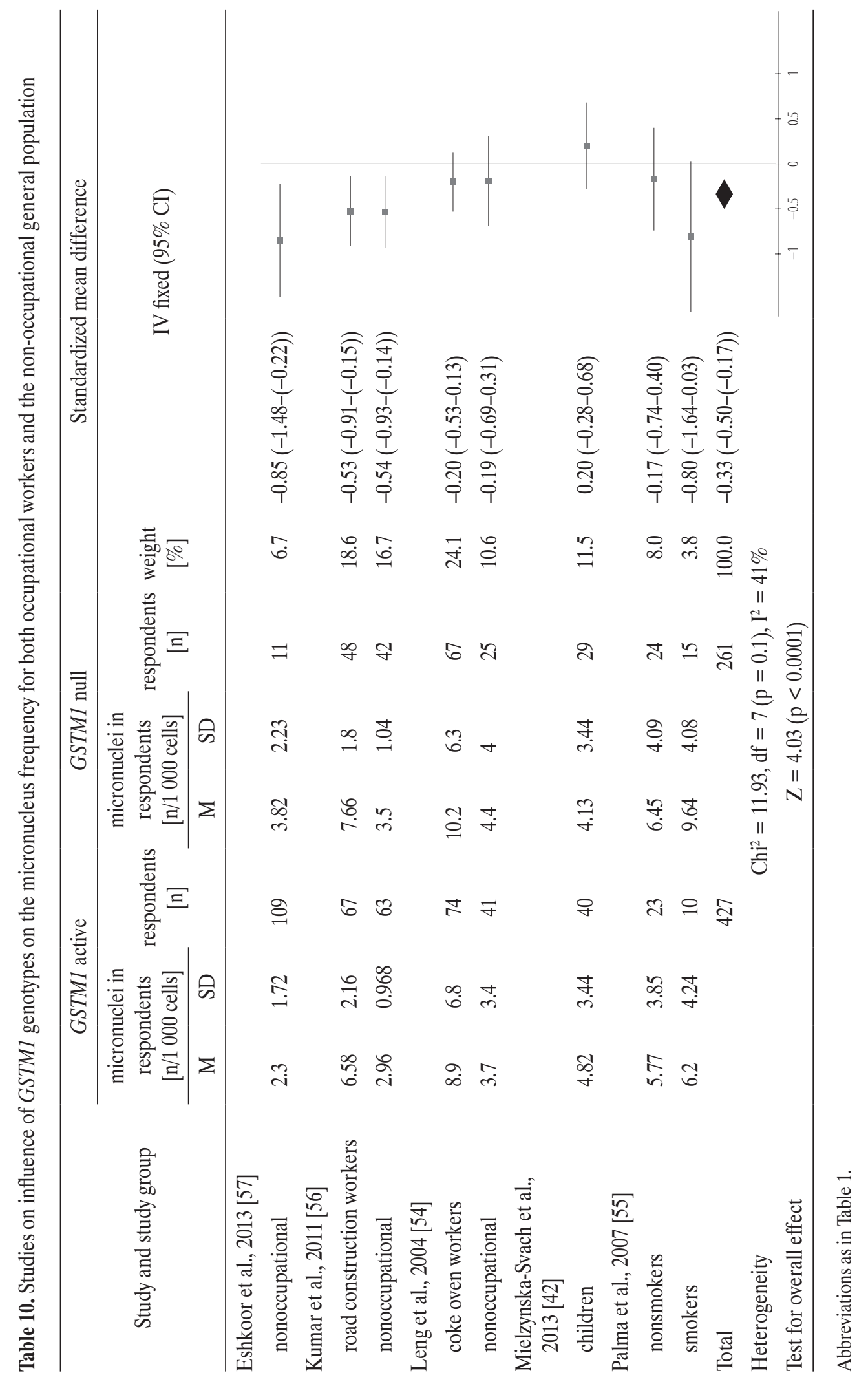




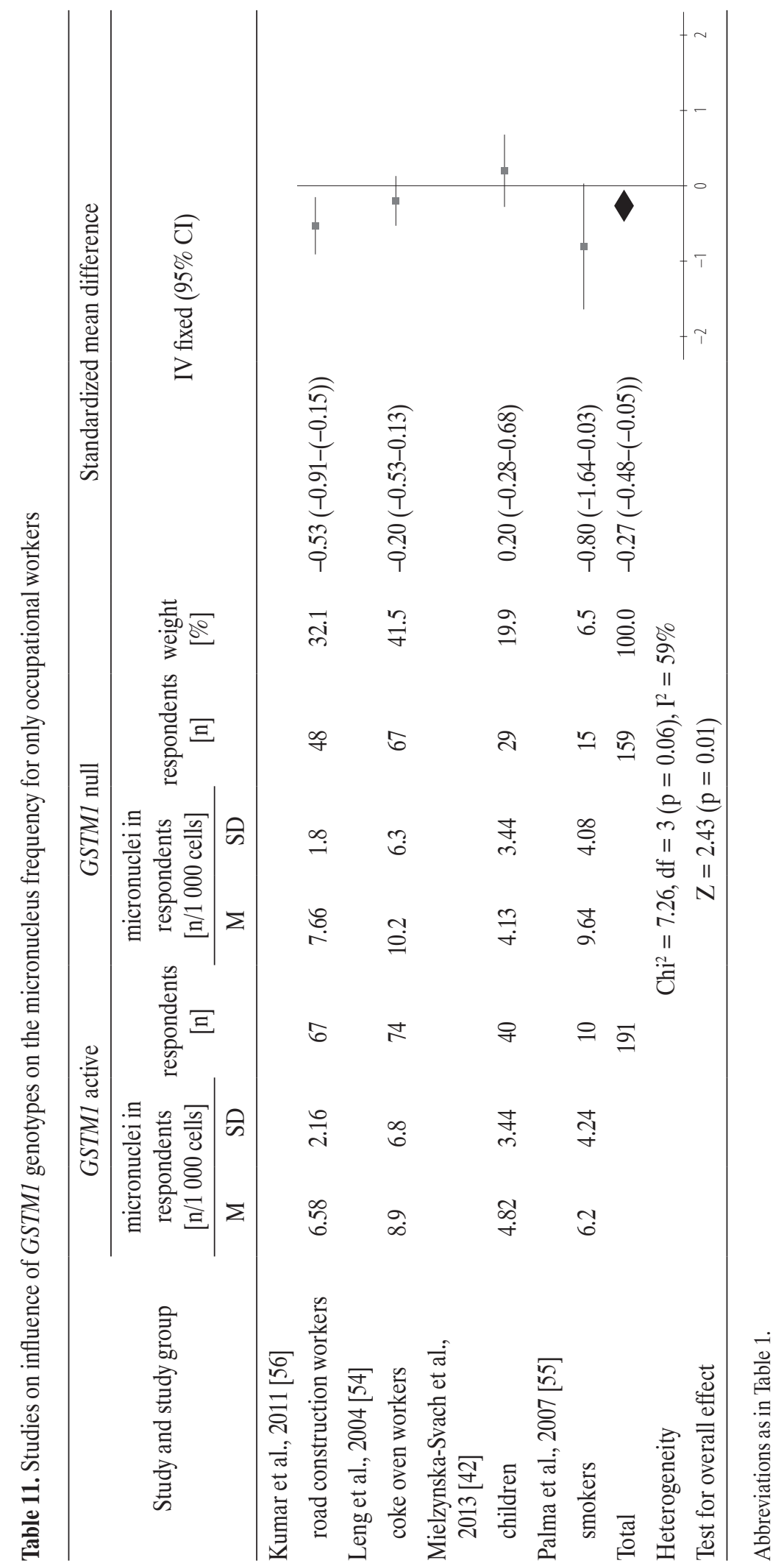

194 IJOMEH 2017;30(2) 


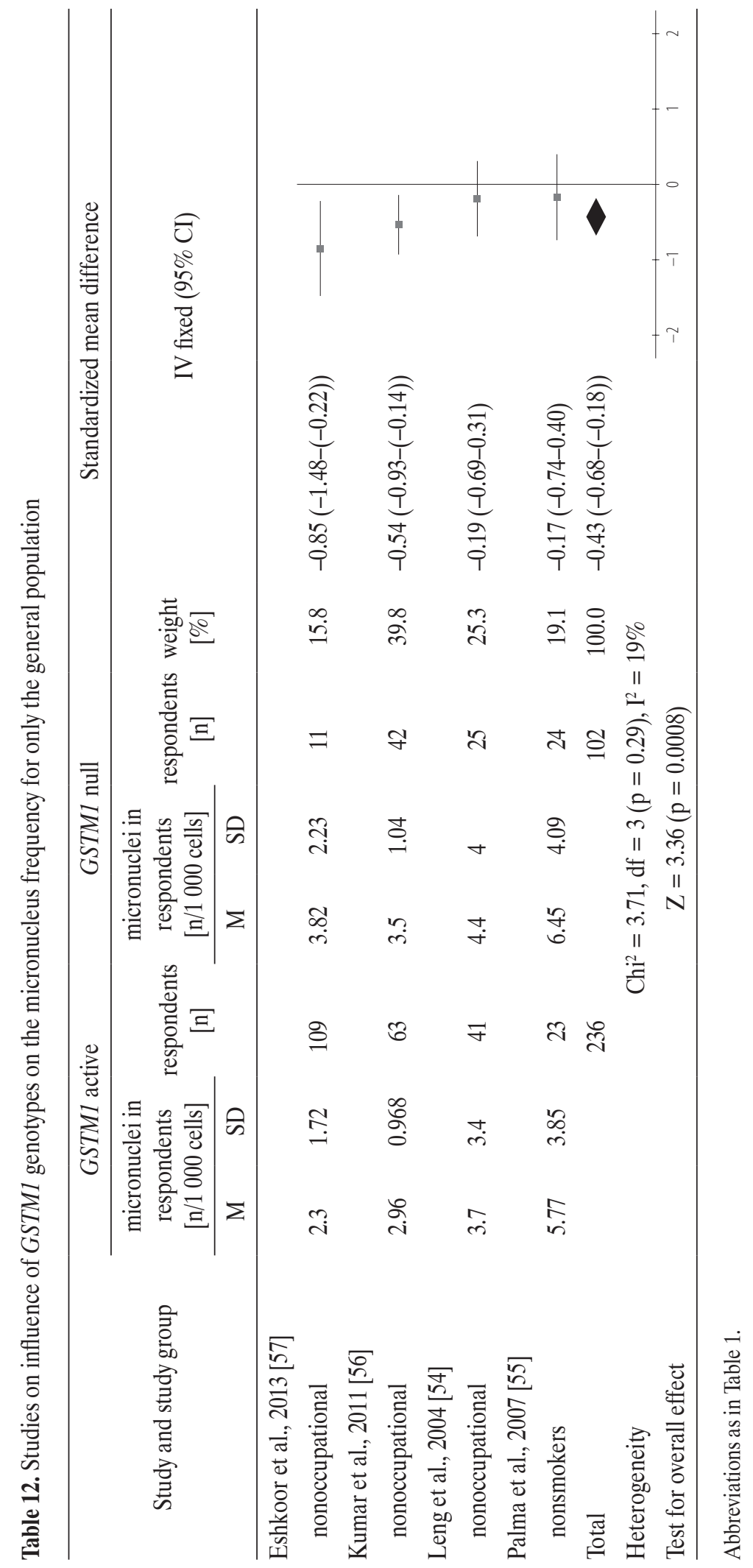


who carried active GSTM1 and null GSTM1 carriers (Table 11). Subjects with the active GSTM1 genotype had a lower micronucleus frequency (SMD $=-0.27,95 \% \mathrm{CI}$ : -0.48 $(-0.05), \mathrm{p}=0.01)$ as compared with the null GSTM1 carriers,. The $\mathrm{I}^{2}$ value was $59 \%$, which indicated moderate heterogeneity, but the $\mathrm{Chi}^{2}$ test showed that the p value was 0.06 . In the 4 non-occupational groups, GSTM1 was found to have similar effects on the micronucleus frequency as in the occupational groups (SMD $=-0.43,95 \%$ CI: -0.68 $(-0.18), \mathrm{p}=0.0008)$, but the $\mathrm{I}^{2}$ value was $19 \%$ (Table 12 ). Funnel plots for both groups showed only a small publication bias (Figure 1c.2 and 1c.3).

\section{DISCUSSION}

Our study presents a comprehensive evaluation of the influence of GSTM1 genotypes on the biological markers commonly used for PAH exposure. Our metaanalysis results indicate that GSTM1 genotypes may affect 1-OHP level and micronucleus frequency. None of GSTM1 carriers showed significantly higher 1-OHP levels in the non-occupational general population and significantly higher micronucleus frequency in both occupational workers and non-occupational exposed general population. Bulky DNA adduct levels seemed no significant association with GSTM1 genotypes.

Our findings that the null GSTM1 genotype was associated with significantly higher levels of 1-OHP in non-occupational environments indicate that the GSTM1 genotype of the individual should be considered when 1-OHP is used for evaluating low levels of PAH exposure. Ciarrocca et al. [12] reviewed that 1-OHP was a reliable biomarker for studying outdoor occupational exposure to PAHs from urban pollution, and the combined concentration of 1-OHP tended to be higher in those with the null GSTM1 than the active GSTM1. The studies included in our analysis indicated that the urinary 1-OHP concentrations in workers with exposure to urban air pollution were all lower than $1 \mu \mathrm{g} / \mathrm{ml}$, which was different from the indoor occupational PAH exposure. Therefore, their results from the meta-analysis were the same as ours for the non-occupational general population.

Our results indicated that in both occupationally exposed workers and non-occupationally exposed general population, the null GSTM1 genotype could not affect the bulky DNA adduct levels, which was inconsistent with another recently published meta-analysis by Liu et al. [24]. For the subgroups of occupational workers, Liu et al. [24] missed 2 studies, and for the non-occupational subgroups, 2 studies were excluded from our analysis and 2 other studies that met the inclusion criteria were included instead. The study by Pavanello et al. [61] was excluded because it measured the level of the benzo[a]pyrene diol epoxide adduct and not the bulky adduct. The other study excluded was the one by Viezzer et al. [48] because it showed high heterogeneity with the other studies, based on the $\mathrm{I}^{2}$ values.

The largest difference in our analysis was that bulky adduct but not benzo[a]pyrene diol epoxide adduct was used. A multicenter European study showed that bulky DNA adducts were positively associated with environmental factors, such as occupational exposure and smoking, while benzo[a]pyrene diol epoxide adducts were more strongly associated with smoking than with the environmental exposure. The multivariate analyses concurrently indicate that GSTM1 genotypes mainly contribute not to bulky DNA adduct but benzo[a]pyrene diol epoxide adduct [27]. To cope with the DNA adduct formation caused by PAH exposure, the human body has developed numerous defensive mechanisms, including DNA repair pathways, such as nucleotide excision repair, that faithfully remove the DNA lesions, including the PAH-DNA adducts $[62,63]$. This may be one of the confounding factors for the unclear difference in the DNA adduct levels between the 2 genotypes of GSTM1.

Our results confirmed the correlation between the different genotypes of GSTM1 and micronucleus frequency. As 
observed for 1-OHP, the null GSTM1 genotype was associated with a significantly higher micronucleus frequency in both the occupational and non-occupational populations. However, the correlation between internal 1-OHP concentrations and micronucleus frequency was still inconsistent, although occupational PAH exposure was associated with higher micronucleus frequency $[64,65]$. DNA-adduct levels, but not 1-OHP, concurrently showed dose-response relationship with micronucleus frequency [65]. This may be explained by that 1-OHP is a specific biomarker reflecting exposure to $\mathrm{PAH}$ mixtures containing pyrene; however, pyrene itself and its metabolites are not genotoxic; micronuclei on the other hand may be formed after exposure to diverse genotoxic agents and not only PAHs.

We tried our best to set strict inclusion criteria for the included studies and concurrently conduct as comprehensive an analysis as possible. Firstly, the articles were chosen from 2 open comprehensive public databases: PubMed and Web of Science. A reasonable search strategy was designed; the language and the period covered by the publications were limited. Most importantly, the detection methods for the biomarkers were restricted for the selected articles. There was no evidence of significant heterogeneity but this meta-analysis may have certain limitations. Since it has been based on published data, the results would be unreliable if a publication bias exists. However, it has been difficult to estimate the extent of a publication bias. Only a low number of subgroups $(\mathrm{N}<10)$ fitted for our final subgroup analysis. Then Egger's test was not used for these subgroup studies. Although there was no evident bias, the possibility of a bias cannot be disregarded.

\section{CONCLUSIONS}

Our results suggest that, as the biomarker of PAH exposure, the 1-OHP level in non-occupationally exposed general population, and micronucleus frequency in both occupational and non-occupational population could be affected by GSTM1 genotypes, while no significant association was found for the level of bulky DNA adducts. None of GSTM1 carriers have seemed more susceptible to PAH damage as it has been indicated by the elevated level of 1-OHP in low levels of PAH exposed population and by high micronucleus frequency observed in both occupational and non-occupational population.

\section{REFERENCES}

1. Polynuclear aromatic compounds. Part 3. Industrial exposures in aluminium production, coal gasification, coke production, and iron and steel foundings. IARC Monogr Eval Carcinog Risk Chem Hum. 1984;34:1-224.

2. Polynuclear aromatic hydrocarbons. Part 2. Carbon blacks, mineral oils (lubricant base oils and derived products) and some nitroarenes. IARC Monogr Eval Carcinog Risk Chem Hum. 1984;33:1-222.

3. Katsouyanni K, Pershagen G. Ambient air pollution exposure and cancer. Cancer Causes Control. 1997;8:284-91, https:// doi.org/10.1023/A:1018492818416.

4. Dockery DW, Pope CA 3rd, Xu X, Spengler JD, Ware JH, Fay ME, et al. An association between air pollution and mortality in 6 U.S. cities. N Engl J Med. 1993;329:1753-9, https:// doi.org/10.1056/NEJM199312093292401.

5. Abbey DE, Hwang BL, Burchette RJ, Vancuren T, Mills PK. Estimated long-term ambient concentrations of $\mathrm{PM}_{10}$ and development of respiratory symptoms in a nonsmoking population. Arch Environ Health. 1995;50:139-52, https://doi.org/10. 1080/00039896.1995.9940891.

6. Pope CA 3rd, Thun MJ, Namboodiri MM, Dockery DW, Evans JS, Speizer FE, et al. Particulate air pollution as a predictor of mortality in a prospective study of U.S. adults. Am J Respir Crit Care Med. 1995;151:669-74, https://doi. org/10.1164/ajrccm/151.3_Pt_1.669.

7. Marczynski B, Raulf-Heimsoth M, Preuss R, Kappler M, Schott K, Pesch B, et al. Assessment of DNA damage in WBCs of workers occupationally exposed to fumes and aerosols of bitumen. Cancer Epidemiol Biomarkers Prev. 2006;15:64551, https://doi.org/10.1158/1055-9965.EPI-05-0562. 
8. García-Suástegui WA, Huerta-Chagoya A, Carrasco-Colín KL, Pratt MM, John K, Petrosyan P, et al. Seasonal variations in the levels of PAH-DNA adducts in young adults living in Mexico City. Mutagenesis. 2011;26:385-91, https://doi. org/10.1093/mutage/geq104.

9. Topinka J, Rossner P Jr., Milcova A, Schmuczerova J, Svecova V, Sram RJ. DNA adducts and oxidative DNA damage induced by organic extracts from PM2.5 in an acellular assay. Toxicol Lett. 2011;202:186-92, https://doi.org/10.1016/ j.toxlet.2011.02.005.

10. Rudel RA, Perovich LJ. Endocrine disrupting chemicals in indoor and outdoor air. Atmos Environ (1994). 2009;43: 170-81, https://doi.org/10.1016/j.atmosenv.2008.09.025.

11. Adonis M, Martinez V, Riquelme R, Ancic P, Gonzalez G, Tapia R, et al. Susceptibility and exposure biomarkers in people exposed to PAHs from diesel exhaust. Toxicol Lett. 2003;144:3-15, https://doi.org/10.1016/S03784274(03)00225-X.

12. Ciarrocca M, Rosati MV, Tomei F, Capozzella A, Andreozzi $\mathrm{G}$, Tomei $\mathrm{G}$, et al. Is urinary 1-hydroxypyrene a valid biomarker for exposure to air pollution in outdoor workers? A meta-analysis. J Expo Sci Environ Epidemiol. 2014;24: 17-26, https://doi.org/10.1038/jes.2012.111.

13. Jongeneelen FJ, Anzion RB, Henderson PT. Determination of hydroxylated metabolites of polycyclic aromatic hydrocarbons in urine. J Chromatogr. 1987;413:227-32, https://doi. org/10.1016/0378-4347(87)80230-X.

14. Apostoli P, Porru S. Biological monitoring and risk assessment. Pavia: Maugeri Foundation Books; 2000.

15. Hopf NB, Carreon T, Talaska G. Biological markers of carcinogenic exposure in the aluminum smelter industry - A systematic review. J Occup Environ Hyg. 2009;6:562-81, https:// doi.org/10.1080/15459620903094810.

16. Peluso M, Srivatanakul P, Munnia A, Jedpiyawongse A, Meunier A, Sangrajrang S, et al. DNA adduct formation among workers in a Thai industrial estate and nearby residents. Sci Total Environ. 2008;389:283-8, https://doi. org/10.1016/j.scitotenv.2007.09.012.
17. Pavanello S, Bollati V, Pesatori AC, Kapka L, Bolognesi C, Bertazzi PA, et al. Global and gene-specific promoter methylation changes are related to anti-B[a]PDE-DNA adduct levels and influence micronuclei levels in polycyclic aromatic hydrocarbon-exposed individuals. Int J Cancer. 2009;125:1692-7, https://doi.org/10.1002/ijc.24492.

18. Peluso M, Munnia A, Piro S, Armillis A, Ceppi M, Matullo G, et al. Smoking, DNA adducts and number of risk DNA repair alleles in lung cancer cases, in subjects with benign lung diseases and in controls. J Nucleic Acids. 2010;2010:386798, https://doi.org/10.4061/2010/386798.

19. Kyrtopoulos SA, Georgiadis P, Autrup H, Demopoulos NA, Farmer P, Haugen A, et al. Biomarkers of genotoxicity of urban air pollution. Overview and descriptive data from a molecular epidemiology study on populations exposed to moderate-to-low levels of polycyclic aromatic hydrocarbons: The AULIS project. Mutat Res. 2001;496:207-28, https:// doi.org/10.1016/S1383-5718(01)00222-4.

20. Schoket B. DNA damage in humans exposed to environmental and dietary polycyclic aromatic hydrocarbons. Mutat Res. 1999;424:143-53, https://doi.org/10.1016/S0027-51 07(99)00015-9.

21. Lesseur C, Gilbert-Diamond D, Andrew AS, Ekstrom RM, Li Z, Kelsey KT, et al. A case-control study of polymorphisms in xenobiotic and arsenic metabolism genes and arsenic-related bladder cancer in New Hampshire. Toxicol Lett. 2012;210:100-6, https://doi.org/10.1016/j.toxlet. 2012.01.015.

22. Karam RA, Pasha HF, El-Shal AS, Rahman HM, Gad DM. Impact of glutathione-S-transferase gene polymorphisms on enzyme activity, lung function and bronchial asthma susceptibility in Egyptian children. Gene. 2012;497:314-9, https:// doi.org/10.1016/j.gene.2012.01.059.

23. Benhamou S, Lee WJ, Alexandrie AK, Boffetta P, Bouchardy C, Butkiewicz D, et al. Meta- and pooled analyses of the effects of glutathione S-transferase M1 polymorphisms and smoking on lung cancer risk. Carcinogenesis. 2002;23:134350, https://doi.org/10.1093/carcin/23.8.1343. 
24. Liu M, Chen L, Zhou R, Wang J. Association between GSTM1 polymorphism and DNA adduct concentration in the occupational workers exposed to PAHs: A metaanalysis. Gene. 2013;519:71-6, https://doi.org/10.1016/j.ge ne.2013.01.045.

25. Hu Y, Li G, Xue X, Zhou Z, Li X, Fu J, et al. PAH-DNA adducts in a Chinese population: Relationship to PAH exposure, smoking and polymorphisms of metabolic and DNA repair genes. Biomarkers. 2008;13:27-40, https://doi. org/10.1080/13547500701671895.

26. Schoket B, Papp G, Levay K, Mrackova G, Kadlubar FF, Vincze I. Impact of metabolic genotypes on levels of biomarkers of genotoxic exposure. Mutat Res. 2001;482:57-69, https://doi.org/10.1016/S0027-5107(01)00210-X.

27. Taioli E, Sram RJ, Binkova B, Kalina I, Popov TA, Garte S, et al. Biomarkers of exposure to carcinogenic PAHs and their relationship with environmental factors. Mutat Res. 2007;620:16-21, https://doi.org/10.1016/j.mrfmmm. 2007.02.018.

28. Xue W, Warshawsky D. Metabolic activation of polycyclic and heterocyclic aromatic hydrocarbons and DNA damage: A review. Toxicol Appl Pharmacol. 2005;206:73-93, https:// doi.org/10.1016/j.taap.2004.11.006.

29. El-Zein RA, Schabath MB, Etzel CJ, Lopez MS, Franklin JD, Spitz MR. Cytokinesis-blocked micronucleus assay as a novel biomarker for lung cancer risk. Cancer Res. 2006;66:6449-56, https://doi.org/10.1158/0008-5472.CAN-06-0326.

30. Fenech M. Cytokinesis-block micronucleus cytome assay. Nat Protoc. 2007;2:1084-104, https://doi.org/10.1038/ nprot.2007.77.

31. Stroup DF, Berlin JA, Morton SC, Olkin I, Williamson GD, Rennie D, et al. Meta-analysis of observational studies in epidemiology: A proposal for reporting. Meta-analysis Of Observational Studies in Epidemiology (MOOSE) group. JAMA. 2000;283:2008-12, https://doi.org/10.1001/ jama.283.15.2008.

32. Shamseer L, Moher D, Clarke M, Ghersi D, Liberati A, Petticrew M, et al. Preferred reporting items for systematic review and meta-analysis protocols (PRISMA-P) 2015: Elaboration and explanation. BMJ. 2015;349:g7647, https://doi. org/10.1136/bmj.g7647.

33. Hozo SP, Djulbegovic B, Hozo I. Estimating the mean and variance from the median, range, and the size of a sample. BMC Med Res Methodol. 2005;5:13, https://doi. org/10.1186/1471-2288-5-13.

34. Higgins JP, White IR, Anzures-Cabrera J. Meta-analysis of skewed data: Combining results reported on log-transformed or raw scales. Stat Med. 2008;27:6072-92, https://doi. $\operatorname{org} / 10.1002 / \operatorname{sim} .3427$.

35. Merlo F, Andreassen A, Weston A, Pan CF, Haugen A, Valerio F, et al. Urinary excretion of 1-hydroxypyrene as a marker for exposure to urban air levels of polycyclic aromatic hydrocarbons. Cancer Epidemiol Biomarkers Prev. 1998;7:147-55.

36. Øvrebø S, Ryberg D, Haugen A, Leira HL. Glutathione S-transferase M1 and P1 genotypes and urinary excretion of 1-hydroxypyrene in coke oven workers. Sci Total Environ. 1998;220:25-31, https://doi.org/10.1016/S0048-96 97(98)00241-1.

37. Alexandrie AK, Warholm M, Carstensen U, Axmon A, Hagmar L, Levin JO, et al. CYP1A1 and GSTM1 polymorphisms affect urinary 1-hydroxypyrene levels after PAH exposure. Carcinogenesis. 2000;21:669-76, https://doi.org/10.1093/car$\operatorname{cin} / 21.4 .669$.

38. Kuljukka-Rabb T, Nylund L, Vaaranrinta R, Savela K, Mutanen P, Veidebaum T, et al. The effect of relevant genotypes on PAH exposure-related biomarkers. J Expo Anal Environ Epidemiol. 2002;12:81-91, https://doi.org/10.1038/ sj.jea. 7500204 .

39. Pavanello S, Pulliero A, Siwinska E, Mielzynska D, Clonfero E. Reduced nucleotide excision repair and GSTM1-null genotypes influence anti-B[a]PDE-DNA adduct levels in mononuclear white blood cells of highly PAH-exposed coke oven workers. Carcinogenesis. 2005;26:169-75, https://doi. org/10.1093/carcin/bgh303.

40. Chuang CY, Chang CC. Urinary 1-hydroxypyrene level relative to vehicle exhaust exposure mediated by metabolic 
enzyme polymorphisms. J Occup Health. 2007;49:140-51, https://doi.org/10.1539/joh.49.140.

41. Ruchirawat M, Settachan D, Navasumrit P, Tuntawiroon J, Autrup H. Assessment of potential cancer risk in children exposed to urban air pollution in Bangkok, Thailand. Toxicol Lett. 2007;168:200-9, https://doi.org/10.1016/j.toxlet.2006.09.013.

42. Mielzynska-Svach D, Blaszczyk E, Butkiewicz D, Durzynska J, Rydzanicz M. Influence of genetic polymorphisms on biomarkers of exposure and effects in children living in Upper Silesia. Mutagenesis. 2013;28:591-9, https://doi. org/10.1093/mutage/get037.

43. Gabbani G, Hou S-M, Nardini B, Marchioro M, Lambert B, Clonfero E. GSTMI and NAT2 genotypes and urinary mutagens in coke oven workers. Carcinogenesis. 1996;17: 1677-81, https://doi.org/10.1093/carcin/17.8.1677.

44. Ada AO, Yilmazer M, Suzen S, Demiroglu C, Demirbag AE, Efe S, et al. Cytochrome P450 (CYP) and glutathione S-transferases (GST) polymorphisms (CYP1A1, CYP1B1, GSTM1, GSTP1 and GSTT1) and urinary levels of 1-hydroxypyrene in Turkish coke oven workers. Genet Mol Biol. 2007;30:511-9, https://doi.org/10.1590/S1415-47 572007000400002 .

45. Zare M, Shahtaheri SJ, Mehdipur P, Abedinejad M, Zare S. The influence of CYP1A1 and GSTM1 polymorphism on the concentration of urinary 1-hydroxypyrene in cPAHs exposed Iranian anode plant workers. Mol Cell Toxicol. 2013;9: 303-9, https://doi.org/10.1007/s13273-013-0038-8.

46. Ichiba M, Hagmar L, Rannug A, Hogstedt B, Alexandrie AK, Carstensen U, et al. Aromatic DNA adducts, micronuclei and genetic polymorphism for CYP1A1 and GST1 in chimney sweeps. Carcinogenesis. 1994;15:1347-52, https:// doi.org/10.1093/carcin/15.7.1347.

47. Binková B, Lewtas J, Míšková I, Leníček J, Šrám R. DNA adducts and personal air monitoring of carcinogenic polycyclic aromatic hydrocarbons in an environmentally exposed population. Carcinogenesis. 1995;16:1037-46, https://doi.org/ 10.1093/carcin/16.5.1037.
48. Viezzer C, Norppa H, Clonfero E, Gabbani G, Mastrangelo G, Hirvonen A, et al. Influence of GSTM1, GSTT1, GSTP1, and EPHX gene polymorphisms on DNA adduct level and HPRT mutant frequency in coke-oven workers. Mutat Res. 1999;431:259-69, https://doi.org/10.1016/S00275107(99)00169-4.

49. Lee J, Kang D, Lee KH, Ichiba M, Zhang J, Tomokuni K, et al. Influence of GSTM1 genotype on association between aromatic DNA adducts and urinary PAH metabolites in incineration workers. Mutat Res. 2002;514:213-21, https://doi. org/10.1016/S1383-5718(01)00340-0.

50. Binkova B, Chvatalova I, Lnenickova Z, Milcova A, Tulupova $\mathrm{E}$, Farmer PB, et al. PAH-DNA adducts in environmentally exposed population in relation to metabolic and DNA repair gene polymorphisms. Mutat Res. 2007;620:49-61, https://doi.org/10.1016/j.mrfmmm.2007.02.022.

51. Molina E, Perez-Morales R, Rubio J, Petrosyan P, Cadena LH, Arlt VM, et al. The GSTM1null (deletion) and MGMT84 rs12917 (Phe/Phe) haplotype are associated with bulky DNA adduct levels in human leukocytes. Mutat Res. 2013;758:62-8, https://doi.org/10.1016/j.mrgentox. 2013.09.007.

52. Fenech M. Cytokinesis-block micronucleus assay evolves into a "cytome" assay of chromosomal instability, mitotic dysfunction and cell death. Mutat Res. 2006;600:58-66, https://doi.org/10.1016/j.mrfmmm.2006.05.028.

53. Thomas P, Umegaki K, Fenech M. Nucleoplasmic bridges are a sensitive measure of chromosome rearrangement in the cytokinesis-block micronucleus assay. Mutagenesis. 2003;18:187-94, https://doi.org/10.1093/mutage/18.2.187.

54. Leng S, Dai Y, Niu Y, Pan Z, Li X, Cheng J, et al. Effects of genetic polymorphisms of metabolic enzymes on cytokinesis-block micronucleus in peripheral blood lymphocyte among coke-oven workers. Cancer Epidemiol Biomarkers Prev. 2004;13:1631-9.

55. Palma S, Cornetta T, Padua L, Cozzi R, Appolloni M, Ievoli E, et al. Influence of glutathione S-transferase polymorphisms on genotoxic effects induced by tobacco smoke. 
Mutat Res. 2007;633:1-12, https://doi.org/10.1016/j.mrgentox.2007.03.014.

56. Kumar A, Yadav A, Giri SK, Dev K, Gautam SK, Gupta R, et al. Effect of genetic polymorphism of GSTM1 and GSTT1 genotypes on cytogenetic biomarkers among coaltar workers. Environ Toxicol Pharmacol. 2011;32:128-35, https://doi. org/10.1016/j.etap.2011.04.002.

57. Eshkoor S, Ismail P, Rahman S, Moin S, Adon M. Role of the CYP1A2 gene polymorphism on early ageing from occupational exposure. Balkan J Med Genet. 2013;16:45-52, https://doi.org/10.2478/bjmg-2013-0031.

58. Villarini M, Moretti M, Fatigoni C, Agea E, Dominici L, Mattioli A, et al. Evaluation of primary DNA damage, cytogenetic biomarkers and genetic polymorphisms for CYP1A1 and GSTM1 in road tunnel construction workers. J Toxicol Environ Health A. 2008;71:1430-9, https://doi. org/10.1080/15287390802328580.

59. Masetti S, Botto N, Manfredi S, Colombo MG, Rizza A, Vassalle $\mathrm{C}$, et al. Interactive effect of the glutathione S-transferase genes and cigarette smoking on occurrence and severity of coronary artery risk. J Mol Med (Berl). 2003;81:488-94, https://doi.org/10.1007/s00109-003-0448-5.

60. Testa A, Festa F, Ranaldi R, Giachelia M, Tirindelli D, de Marco A, et al. A multi-biomarker analysis of DNA damage in automobile painters. Environ Mol Mutagen. 2005;46: 182-8, https://doi.org/10.1002/em.20147.
61. Pavanello S, Pulliero A, Clonfero E. Influence of GSTM1 null and low repair XPC PAT+ on anti-B[a]PDE-DNA adduct in mononuclear white blood cells of subjects low exposed to PAHs through smoking and diet. Mutat Res. 2008;638: 195-204, https://doi.org/10.1016/j.mrfmmm.2007.10.004.

62. Xu G, Spivak G, Mitchell DL, Mori T, McCarrey JR, McMahan CA, et al. Nucleotide excision repair activity varies among murine spermatogenic cell types. Biol Reprod. 2005;73:12330, https://doi.org/10.1095/biolreprod.104.039123.

63. Crew KD, Gammon MD, Terry MB, Zhang FF, Zablotska LB, Agrawal M, et al. Polymorphisms in nucleotide excision repair genes, polycyclic aromatic hydrocarbon-DNA adducts, and breast cancer risk. Cancer Epidemiol Biomarkers Prev. 2007;16:2033-41, https://doi.org/10.1158/1055-99 65.EPI-07-0096.

64. Liu AL, Lu WQ, Wang ZZ, Chen WH, Lu WH, Yuan J, et al. Elevated levels of urinary 8-hydroxy-2-deoxyguanosine, lymphocytic micronuclei, and serum glutathione S-transferase in workers exposed to coke oven emissions. Environ Health Perspect. 2006;114:673-7, https://doi.org/10.1289/ehp.8562.

65. Pavanello S, Kapka L, Siwinska E, Mielzynska D, Bolognesi C, Clonfero E. Micronuclei related to anti-B[a]PDE-DNA adduct in peripheral blood lymphocytes of heavily polycyclic aromatic hydrocarbon-exposed nonsmoking coke-oven workers and controls. Cancer Epidemiol Biomarkers Prev. 2008;17: 2795-9, https://doi.org/10.1158/1055-9965.EPI-08-0346.

This work is available in Open Access model and licensed under a Creative Commons Attribution-NonCommercial 3.0 Poland License - http://creativecommons.org/ licenses/by-nc/3.0/pl/deed.en. 